\title{
Hubungan Mode Adaptif Konsep Diri Berbasis Teori Callista Roy dengan Kemampuan Interaksi Sosial Anak Tunagrahita di SLB-C TPA Kabupaten Jember (The Correlation Between Adaptive Modes: Self Concept Based on Callista Roy's Theory and Social Interaction Abilities to Mental Retardation Children on SLB-C TPA at Jember Regency)
}

\author{
Zuhrotul Rofiqoh, Nurfika Asmaningrum, Dodi Wijaya \\ Fakultas Keperawatan, Universitas Jember \\ JI. Kalimantan No. 37 Kampus Tegal Boto Telp./Fax (0331) 323450 \\ e-mail :dodi.wijaya@unej.ac.id
}

\begin{abstract}
Self concept is one of adaptive modes based on Callista Roy's theory which very important for mental deficiency influence integrity of mental in practice to had a good social interaction. The kind of this research is descriptive analytic by using study cross sectional. Method of collecting samples using total sampling and total of samples got are 35 respondents. Data was analyzed by chi-square and the result of statistical test shows point $p=0.000$. Ha is accepted if Ho is rejected in which Ho is rejected if the point is $p \leq \alpha, 0,000 \leq 0,05$. The result of the statistic analysis is that there is significant correlation between adaptive modes: self concept based on Callista Roy's theory and social interaction abilities to mental retardation children on SLB-C TPA at Jember Regency. OR (26.00), that means the respondents who had a positive self concept have 26.00 possibility to be had a good social interaction abilities. The result of the research is positive self concept with good social interaction ability about $80 \%$. Suggests for nursing in community to involve and increase their role model as educator and care giver in attempt to share information by doing a counseling.
\end{abstract}

Keywords: self concept, social interaction, mental retardation

\begin{abstract}
Abstrak
Konsep diri adalah salah satu mode adaptif berdasarkan teori Callista Roy yang sangat penting bagi tunagrahita dengan defisiensi konsep diri untuk mencapai kemampuan interaksi sosial yang baik. Jenis penelitian ini adalah analitik deskriptif studi cross sectional. Metode pengumpulan sampel menggunakan total sampling dan jumlah sampel 35 responden. Data dianalisis dengan chi-square dan hasil uji statistik menunjukkan nilai $p=0.000$. Ha diterima jika Ho ditolak di mana Ho ditolak jika $p \leq \alpha, 0,000 \leq 0,05$. Hasil analisis statistik diketahui bahwa ada hubungan yang signifikan antara mode adaptif konsep diri berbasis teori Callista Roy dan kemampuan interaksi sosial kemampuan anak tunagrahita di SLB-C TPA Kabupaten Jember. OR (26.00), artinya responden yang yang memiliki konsep diri positif 26 kali risiko memiliki kemampuan interaksi sosial yang baik. Hasil penelitian ini adalah konsep diri positif dengan kemampuan interaksi sosial yang baik sekitar $80 \%$. Diharapkan pada tenaga kesehatan khususnya bidang keperawatan di masyarakat untuk melibatkan diri dan meningkatkan peran sebagai pendidik dan care giver dalam upaya untuk meningkatkan konsep diri dan pemberian informasi dengan melakukan konseling.
\end{abstract}

Kata kunci: konsep diri, interaksi sosial, tunagrahita 


\section{Pendahuluan}

Manusia adalah makhluk sosial sekaligus makhluk individual. Sebagai makhluk sosial, manusia memiliki motif atau dorongan untuk mengadakan hubungan dan hidup bersama dengan orang lain dan lingkungan dimana manusia tersebut berada. Sementara itu, sebagai makhluk individual, manusia memiliki motif untuk mengadakan hubungan dengan dirinya sendiri [1]. Hubungan dengan diri manusia sendiri inilah yang merupakan pembentukan awal untuk mengevaluasi diri sendiri dan memperoleh suatu kemampuan [2]. Kemampuan sosial merupakan tindakan manusia untuk mencapai hubungan timbal balik dengan orang lain yang disebut dengan interaksi sosial. Kemampuan sosial manusia dapat berkembang pada setiap tahap tumbuh kembang manusia yang mulai dibentuk saat usia kanak-kanak [3].

Anak mengembangkan kemampuan sosial dengan mengenali diri sendiri dan teman sebayanya sebagai individu yang unik sehingga mendorong anak tersebut untuk bergaul lebih akrab dengan teman sebayanya. Anak (usia 712 tahun) pada umumnya belum memiliki konsep diri sosial yang jelas, yaitu konsep diri dengan teman sebaya (peers) dan konsep diri terhadap orang berpengaruh (significant others), yaitu orang tua dan guru. Konsep diri yang belum jelas terlihat pada sikap anak yang cenderung sulit untuk berinteraksi sosial karena berbagai faktor, salah satunya adalah kurangnya pengetahuan [4].

Indonesia memiliki 679.048 ABK usia sekolah atau setara dengan $21,42 \%$ dari jumlah keseluruhan ABK $[5,6]$. Jumlah ABK tunagrahita di Indonesia dengan usia sekolah (7-12 tahun) masih dalam kategori tinggi dan khususnya yang perlu mendapat perhatian serius mencapai 1,2 juta orang atau $2,5 \%$ dari populasi anakanak usia sekolah [7]. Data ini menunjukkan bahwa masih terdapat populasi ABK tunagrahita usia sekolah di Indonesia yang memerlukan perhatian serius dan memperoleh kesempatan pendidikan yang sama serta kualitasnya perlu dikembangkan untuk mencapai kemampuan penyesuaian sosial dengan baik $[8,9]$.

ABK tunagrahita mengalami hambatan dalam berinteraksi sosial karena kurangnya pengetahuan khususnya intelegensi, motivasi dan bimbingan dalam pembentukan konsep diri. Anak tunagrahita memiliki ketergantungan pada orang lain secara berlebihan, kurang tanggap, penampilan fisiknya kurang proporsional, dan perkembangan bicara terlambat serta bahasanya pun terbatas bila dibandingkan ABK yang lainnya [5]. Interaksi sosial pada anak tunagrahita dapat dikembangkan dengan pembentukan konsep diri yang merupakan salah satu cara untuk mempertahankan adaptasi anak tunagrahita dengan lingkungannya.

Teori yang menjelaskan tentang pertahanan adaptasi dipopulerkan oleh Callista Roy pada tahun 1960. Roy mengembangkan model konseptual keperawatan dalam buku yang berjudul "Introduction to Nursing: An Adaptation Model" dengan konsep utama mode adaptif[10]. Roy melalui teorinya memandang manusia sebagai sistem terbuka. Sistem terbuka yang dimaksud adalah manusia khususnya ABK tunagrahita terus menerus mendapatkan stimulus (stress) regulator ataupun stimulus kognator. Stimulus regulator merupakan stimulus secara biologis yang terjadi di dalam diri manusia. Stimulus kognator merupakan stimulus yang berhubungan dengan psikologis, sosial, fisik dan fisiologis yang menyebabkan terjadinya proses koping yang berhubungan dengan emosi dan persepsi [11].

Roy mengungkapkan suatu mekanisme koping di dalam diri manusia yang diwujudkan dalam bentuk perilaku koping untuk mengatasi stimulus (stress). Perilaku koping ini disebut dengan mode adaptif. Mode adaptif ini dapat mengarah pada perilaku koping yang positif maupun yang negatif. Mode adaptif terdiri dari empat komponen, yaitu: (1) kebutuhan fisologis; (2) konsep diri; (3) fungsi peran; dan (4) interdependensi [12]. Konsep diri yang dijelaskan oleh Roy merujuk pada kebutuhan integritas mental dengan cara berinteraksi dengan diri sendiri dan orang lain. Interaksi dengan diri sendiri yang merupakan dasar perilaku koping meliputi: physical self dan personal self. Physical self terdiri dari sensasi diri dan gambaran diri. Personal self terdiri dari konsistensi diri, ideal diri, serta moral etik dan spiritual. Konsep diri berdasarkan teori Roy merupakan keadaan emosi tertentu yang dialami oleh anak tunagrahita yang meliputi semua ide, pikiran, kepercayaan dan pendirian individu tentang dirinya sendiri secara secara utuh baik dari segi fisikal, emosional, intelektual, sosial, dan spiritual yang dikembangkan melalui proses yang sangat kompleks dan melibatkan banyak hal, salah satunya adalah hubungan dengan diri sendiri dan orang lain. Hal yang terpenting dari penerapan teori Roy terhadap anak tunagrahita adalah bagaimana cara memandirikan anak tunagrahita yang semula 
bergantung pada orang lain dan menjadi mandiri pada akhirnya [13].

\section{Metode Penelitian}

Jenis penelitian ini adalah penelitian deskriptif analitik dengan metode pendekatan cross sectional. Sampel dalam penelitian ini berjumlah 35 orang. Teknik pengambilan sampling yaitu menggunakan total sampling. Teknik pengumpulan data dalam penelitian ini yaitu dengan menggunakan kuesioner mode adaptif konsep diri berbasis teori Callista Roy dan kemampuan interaksi sosial yang dibagikan kepada responden. Data yang diperoleh dianalisis menggunakan uji statistik chisquare untuk mengetahui hubungan mode adaptif konsep diri berbasis teori Callista Roy dengan kemampuan interaksi sosial.

\section{Hasil Penelitian}

\section{Mode Adaptif Konsep Diri Berbasis Teori Callista Roy}

Berdasarkan tabel 1 responden di SLB-C TPA Kabupaten Jember sebagian besar memiliki sensasi diri yang positif, yaitu sebanyak 25 orang $(71.4 \%)$, memiliki gambaran diri positif, yaitu sebanyak 21 orang $(60 \%)$, konsistensi diri yang positif, yaitu 28 orang $(80 \%)$, ideal diri positif, yaitu sebanyak 29 orang (82.9\%). Sebagian besar responden memiliki moral etik dan spiritual positif, yaitu sebanyak 25 orang (71.4\%).

Tabel 2. Gambaran Distribusi Mode Adaptif Konsep diri Berbasis Teori Callista Roy

\begin{tabular}{llll}
\hline No & $\begin{array}{l}\text { Mode Adaptif } \\
\text { Konsep diri } \\
\text { Berbasis Teori } \\
\text { Callista Roy }\end{array}$ & $\begin{array}{l}\text { Frekuensi } \\
\text { (orang) }\end{array}$ & $\begin{array}{l}\text { Persentas } \\
\text { e (\%) }\end{array}$ \\
\hline 1. & Positif & 18 & 51.4 \\
2. & Negatif & 17 & 48.6 \\
\hline & Total & $\mathbf{3 5}$ & $\mathbf{1 0 0}$ \\
\hline
\end{tabular}

\section{Kemampuan Interaksi Sosial Anak Tunagrahita di SLB-C TPA Kabupaten Jember}

Tabel 3 menunjukkan gambaran distribusi frekuensi indikator kemampuan interaksi sosial yang dapat dianalisis bahwa jumlah responden yang memiliki kontak sosial baik lebih banyak, yaitu sebanyak 22 orang (62.9\%). Jumlah responden yang memiliki aktivitas bersama kategori baik lebih banyak, yaitu 19 orang $(54.3 \%)$ dan jumlah responden yang memiliki frekuensi interaksi baik lebih banyak, yaitu 22 orang (62.9\%) bila dibandingkan dengan responden yang memiliki frekuensi yang tidak baik.

Tabel 4. Gambaran Distribusi Kemampuan Interaksi Sosial Anak Tunagrahita di SLB-C TPA Kabupaten Jember

\begin{tabular}{llll}
\hline Variabel & Kategori & Jumlah & $\begin{array}{l}\text { Persentase } \\
(\%)\end{array}$ \\
\hline $\begin{array}{l}\text { Kemampuan } \\
\text { interaksi } \\
\text { sosial }\end{array}$ & Baik & 20 & 57.1 \\
\cline { 2 - 4 } & $\begin{array}{l}\text { Tidak } \\
\text { baik }\end{array}$ & 15 & 42.9 \\
\hline Total & & 35 & $\mathbf{1 0 0}$ \\
\hline
\end{tabular}

\section{Hubungan Mode Adaptif Konsep Diri Berbasis Teori Callista Roy dengan Kemampuan Interaksi Sosial Anak Tunagrahita di SLB-C TPA Kabupaten Jember.}

Tabel 5. Tabulasi Silang Hubungan Mode Adaptif Konsep Diri Berbasis Teori Callista Roy dengan Kemampuan Interaksi Sosial Anak Tunagrahita di SLB-C TPA Kabupaten Jember

\begin{tabular}{|c|c|c|c|c|c|c|c|c|}
\hline \multirow{4}{*}{$\begin{array}{l}\text { Mode } \\
\text { adaptif } \\
\text { konsep } \\
\text { diri } \\
\text { berbasi } \\
\text { s teori } \\
\text { Callista } \\
\text { Roy }\end{array}$} & \multirow{2}{*}{\multicolumn{4}{|c|}{$\begin{array}{l}\text { Kemampuan } \\
\text { interaksi sosial }\end{array}$}} & \multirow{2}{*}{\multicolumn{2}{|c|}{ Total }} & \multirow{4}{*}{ OR } & \multirow{4}{*}{$p$} \\
\hline & & & & & & & & \\
\hline & \multicolumn{2}{|c|}{$\begin{array}{c}\text { Tidak } \\
\text { baik }\end{array}$} & \multicolumn{2}{|c|}{ Baik } & \multirow[b]{2}{*}{$\mathbf{F}$} & \multirow[b]{2}{*}{$\%$} & & \\
\hline & $\mathbf{F}$ & $\%$ & $F$ & $\%$ & & & & \\
\hline Negatif & 13 & $\begin{array}{l}86 . \\
7\end{array}$ & 4 & $\begin{array}{l}20 \\
.0\end{array}$ & 17 & $\begin{array}{l}48 . \\
6\end{array}$ & 26 & 0 \\
\hline Positif & 2 & $\begin{array}{l}13 . \\
3\end{array}$ & 16 & $\begin{array}{l}80 \\
.0\end{array}$ & 18 & $\begin{array}{l}51 . \\
4\end{array}$ & & \\
\hline Total & 15 & 100 & 20 & $\begin{array}{l}10 \\
0\end{array}$ & 35 & $\begin{array}{l}10 \\
0\end{array}$ & & \\
\hline
\end{tabular}

Tabel 5 menunjukkan hasil uji statistik chi square dengan nilai $p=0.000$. Ha diterima jika jika nilai $p \leq \alpha, 0,000 \leq 0,05$. Hasil analisis statistik didapatkan bahwa ada hubungan antara mode adaptif konsep diri berbasis teori Callista Roy dengan kemampuan interaksi sosial anak tunagrahita di SLB-C TPA Kabupaten Jember. Parameter kekuatan hubungan yang digunakan adalah OR (odds ratio), yaitu sebesar 26.00 dengan keyakinan interval 95\% 4.095-165.095 artinya, anak tunagrahita dengan konsep diri positif mempunyai risiko 26 kali memiliki kemampuan interaksi sosial yang baik dibandingkan dengan anak tunagrahita yang memiliki konsep diri yang negatif. Nilai OR sebesar 26.00 dapat diartikan bahwa probabilitas responden yang memiliki konsep diri positif dan baik dalam berinteraksi sosial adalah sebesar $96.2 \%$. 


\section{Pembahasan}

\section{Karakteristik Responden di SLB-C TPA Kabupaten Jember}

Berdasarkan hasil penelitian yang dilakukan selama Bulan Agustus di SLB-C TPA Kabupaten Jember tentang karakteristik responden, yaitu umur dan jenis kelamin didapatkan bahwa terdapat anak tunagrahita dalam rentang usia 17-25 tahun dan masih berada di tingkat sekolah dasar di SLB-C TPA Kabupaten Jember dan tidak terdapat perbedaan yang signifikan antara jumlah anak laki-laki dan perempuan karena jumlah diantara keduanya hampir sama. Faktor yang dapat mempengaruhi kemampuan interaksi sosial dan konsep diri adalah perkembangan umur dan gender. Umur berkaitan dengan tahap perkembangan dan komunikasi yang mengarah pada suatu kemampuan siswa untuk berinteraksi sosial. Kemampuan interaksi sosial antar siswa berbeda karena setiap individu memiliki perkembangan bahasa dan proses berpikir yang berbeda sesuai dengan tingkat perkembangan umurnya. Umur sangat erat kaitannya dengan perkembangan neurologi dan intelektual [12].

Faktor yang dapat mempengaruhi kemampuan interaksi sosial selain umur adalah jenis kelamin (gender). Jenis kelamin laki-laki dan perempuan memiliki gaya komunikasi dan kemampuan interaksi sosial yang berbeda. Lakilaki cenderung memiliki minat untuk melakukan interaksi sosial dalam kelompok besar sedangkan perempuan lebih berminat berkomunikasi atau berinteraksi sosial dalam kelompok kecil [12]. Keadaan ini dapat dihubungkan dengan penelitian yang dilakukan oleh peneliti di SLB-C TPA Kabupaten Jember bahwa siswa dengan jenis kelamin perempuan lebih tertarik untuk berkomunikasi antar personal saja sedangkan siswa laki-laki lebih tertarik berkomunikasi atau melakukan interaksi sosial dengan kelompok teman-teman yang lebih banyak dan cenderung tertarik untuk mengenal teman-teman dengan populasi yang lebih banyak.

Konsep diri terbentuk seiring dengan bertambahnya umur seseorang. Perbedaan usia ini memiliki keterkaitan dengan tugas perkembangan. Masa sekolah merupakan masa dimana pada masa ini seorang anak menggabungkan umpan balik dari teman sebaya dan lingkungan sosial selain keluarga mulai mempengaruhi pandangan dan juga penilaian individu terhadap dirinya. Tahap ini disebut dengan tahap perkembangan diri. Anak mulai belajar untuk bisa mengatasi berbagai macam masalah secara rasional. Pertumbuhan menjadi cepat dan lebih banyak didapatkan keterampilan motorik, sosial dan intelektual. Konsep diri dan citra tubuh dapat berubah pada masa ini karena anak terus mengalami perubahan secara fisik yang berbeda antara laki-laki dan perempuan, emosional, mental dan sosial $[14,15]$.

\section{Mode Adaptif Konsep Diri Berbasis Teori Callista Roy}

Siswa yang di SLB-C yang memiliki konsep diri negatif cenderung merasa tidak percaya diri, sering menyendiri dan tidak antusias untuk mengembangkan aktivitas yang dilakukannya. Siswa yang memiliki konsep diri yang positif memiliki karakter yang cenderung percaya diri, mampu beradaptasi dengan lingkungan di sekitar dan memiliki sikap untuk mencapai cita-citanya. Jenis konsep diri dibagi menjadi dua, yaitu konsep diri positif dan konsep diri negatif. Konsep diri dikatakan positif jika individu yang memiliki konsep diri positif akan mampu menerima kekurangan dalam dirinya. Individu tersebut akan mampu mengintrospeksi dirinya dan mampu mengubah dirinya agar menjadi lebih baik, mampu menata masa depannya dengan sikap optimis sehingga dapat diterima di tengah masyarakat. Individu yang memiliki konsep diri yang positif akan selalu optimis, berani mencoba hal-hal baru, berani sukses, berani gagal, percaya diri, antusias, merasa diri berharga, berani menetapkan tujuan hidup, bersikap dan berpikir positif dan dapat menjadi pemimpin yang handal serta memiliki penyesuaian sosial yang baik [16].

Konsep diri positif membuat individu akan memandang positf dirinya maupun orang lain dan individu akan mendapat umpan balik yang positif juga dari lingkungannya [17]. Konsep diri dikatakan negatif apabila individu memandang dirinya secara acak, tidak teratur, tidak stabil, dan tidak ada keutuhan diri. Individu tidak mengetahui siapa dirinya, kelemahannya, kelebihannya, serta apa yang dihargai dalam hidupnya. Individu menjadi seorang yang kaku dan tidak bisa menerima ide-ide baru yang bermanfaat baginya. Konsep diri yang negatif akan mengakibatkan rasa tidak percaya diri, tidak berani mencoba hal-hal baru, tidak berani mencoba hal-hal menantang, takut gagal, takut sukses, dan pesimis serta memiliki tingkah laku yang tidak terarah. 


\section{Kemampuan Interaksi Sosial Anak Tunagrahita di SLB-C TPA Kabupaten Jember}

Kemampuan interaksi sosial dikatakan tidak baik ketika kondisi individu atau kelompok berkeinginan untuk melakukan komunikasi atau interaksi, akan tetapi ada sejumlah faktor yang menghambat proses yang ada dalam interaksi ada. Interaksi sosial dikatakan baik apabila seseorang mau dan berkeinginan untuk berkomunikasi dan melakukan aktivitas bersama dengan orang lain. Faktor-faktor yang mempengaruhi interaksi sosial antara lain jenis kelamin, umur, lingkungan, sosiokultural, dan persepsi [12]. Lingkungan yang dimaksud adalah lingkungan di sekitar individu sehingga dapat mempengaruhi dalam penyesuaian interaksi sosial dengan orang lain. Latar belakang budaya yang dimiliki dapat mempengaruhi tingkah laku individu dalam melakukan interaksi sosial [18]. Interaksi sosial juga dipengaruhi oleh pengetahuan yang dimiliki oleh seseorang. Interaksi yang diawali dengan komunikasi akan menjadi sulit ketika orang yang berkomunikasi memiliki tingkat pengetahuan yang berbeda.

Kenyataan di lapangan didapatkan bahwa kemampuan interaksi yang tidak baik dari responden dapat disebabkan karena responden sulit untuk mengenal dan beradaptasi dengan teman-teman yang mereka masih belum mengenalnya. Responden hanya mengenal teman-teman yang terbiasa bermain atau berkumpul dengan mereka sehari-seharinya. Responden tidak akrab dan sulit berinteraksi dengan orang disekitar atau dengan kata lain menarik diri dari orang-orang baru yang belum mereka kenal sebelumnya karena merasa takut dan kurangnya perhatian dan bimbingan orang tua membuat anak cenderung tidak percaya diri dalam melakukan komunikasi dengan orang lain. Responden yang memiliki kemampuan interaksi sosial yang baik adalah responden yang selalu mendapat perhatian orang tua mereka. Pentingnya suatu motivasi yang diberikan oleh orang tua dapat menjadi tuntunan bagi anak untuk melakukan hal yang dikehendaki. Motivasi merupakan sebuah dorongan atau kekuatan yang berasal dari individu itu sendiri atau berasal dari support system dari orang-orang disekeliling individu tersebut dan dapat mempengaruhi seseorang dalam melakukan interaksi sosial.

e-Jurnal Pustaka Kesehatan, vol.6 (no.2), Mei, 2018

\section{Hubungan Mode Adaptif Konsep Diri Berbasis Teori Callista Roy dengan Kemampuan Interaksi Sosial Anak Tunagrahita}

Sebagian besar kemampuan interaksi sosial anak tunagrahita di SLB-C TPA Kabupaten Jember tidak baik pada responden yang memiliki konsep diri yang negatif karena konsep diri yang negatif cenderung kurang antusias dan percaya diri dalam berkomunikasi dengan orang di sekitarnya serta kurangnya bimbingan dari orang tua anak. Akan tetapi masih ada responden yang mampu berinteraksi dengan baik walaupun memiliki konsep diri yang negatif karena anak senang beraktivitas dengan orang di sekelilingnya. Anak yang memiliki kemampuan interaksi sosial tidak baik namun memiliki konsep diri positif biasanya mereka lebih suka menyendiri dan memiliki pribadi yang tertutup. Anak mampu berinteraksi sosial dengan baik dan memiliki konsep dri yang positif karena besarnya dukungan dari orang tua dan guru yang membangun konsep diri mereka.

Konsep diri adalah kumpulan dari kepercayaan. Konsep diri terdiri dari perasaan dan pikiran tentang kelebihan dan kelemahan, kemampuan dan keterbatasan diri yang dibangun berdasarkan gambaran diri terhadap pihak lain yang didapatkan dari interaksi dengan orang lain [19]. Interaksi sosial dikenal dengan komunikasi interpersonal yang merupakan suatu bentuk praktek dan proses belajar dengan berbagai orang dan budaya yang ada serta cara mengevaluasi dan menginterpretasikan perilaku dan pikiran yang akhirnya membentuk suatu konsep diri pada seseorang. Perlunya suatu bimbingan orang tua dan guru dalam mendidik anak tunagrahita agar mereka lebih mau untuk melakukan interaksi dan memiliki konsep diri yang positif. Motivasi yang diberikan diharapkan dapat mendorong anak untuk lebih optimis dan percaya diri. Anak tunagrahita yang mempunyai kesulitan akan mendapat bimbingan dari guru pembimbing khusus untuk meningkatkan kemampuan interaksinya [20].

\section{Simpulan dan Saran}

Terdapat pengaruh ROM aktif kaki terhadap risiko ulkus kaki diabetik pada pasien DM tipe 2. ROM aktif kaki dapat meningkatkan sirkulasi darah ekstemitas bawah sehingga menurunkan risiko ulkus kaki diabetik pada pasien DM tipe 2. Perawat dapat memberikan pendidikan kesehatan mengenai ROM aktif kaki sehingga risiko ulkus kaki diabetik dapat diminimalkan. Bagi peneliti selanjutnya 
diperlukan durasi latihan yang lebih lama dan jumlah responden yang lebih banyak dengan pengontrolan faktor-faktor yang mempengaruhi ulkus kaki diabetik.

\section{Daftar pustaka}

[1] American Diabetes Association. Type 2 diabetes mellitus. [Internet] ADA; 2014 [diambil tanggal 25 November 2015]; dari: http://www.diabetes.org/diabetesbasics/statistics/

[2] International Diabetes Federation. IDF diabetes atlas : sixth edition. [Internet] IDF; 2013 [diambil tanggal 02 Juni 2015]; dari: http://www.idf.org/sites/default/files/EN 6E_ Atlas_Full 0.pdf

[3] Perkumpulan Endokrinologi Indonesia. Konsensus pengelolaan diabetes melitus di Indonesia. [Internet] PERKENI, 2011 [diambil tanggal 26 November 2011]; dari: https://www.scribd.com/doc/234334110/Kon sensus-DM-Perkeni-2011\#download

[4] International Diabetes Federation. IDF diabetes atlas : 7th edition. [Internet] IDF;2015 [diambil tanggal 12 Januai 2016]; dari: $\quad$ http://www.diabetesatlas.org/keymessages.html

[5] Badan Penelitian dan Pengembangan Kesehatan Depkes RI. Riset Kesehatan Dasar (RISKESDAS) 2013. Jakarta : Badan Penelitian dan Pengembangan Kesehatan Depkes RI; 2013

[6] Dinas Kesehatan Kabupaten Jember. Laporan kunjungan DM Kabupaten Jember tahun 2015. Jember : Dinas Kesehatan Kabupaten Jember; 2015

[7] Mahendra. Care your self : diabetes mellitus [Intenet] Jakarta : 2008.[diambil tanggal 1 Juni 2015]; dari: https://books.google.co.id/books? id=iu18116ceAEC\&pg=PA17\&dq=Dampak + diabetes+mellitus\&hl=en\&sa $=X \&$ ei $=h Y F r V Z$ CUHdWcugTD-

[8] Hastuti R. Faktor risiko ulkus diabetika pada penderita diabetes melitus. Tesis. Semarang: Program Studi Magister Epidemiologi Universitas Diponegoro; 2008.

[9] Lumenta NA. Manajemen hidup sehat [Internet] Jakarta: PT Elex Media Komputindo; 2006. [diambil tanggal 16 Oktober 2015] dari: https://books.google.co.id/books? id=g5Lbitu6jPoC\&pg=PA30\&dq=perjalanan +kaki+diabetik\&hl=en\&sa

[10] Roza RL, Afriant R, Edward Z. Faktor risiko terjadinya ulkus diabetikum pada pasien diabetes melitus yang dirawat jalan dan inap di RSUP Dr. M.Djamil dan RSI Ibnu Sina Padang. Jurnal Kesehatan Andalas [Internet]. 2015 [diambil tanggal 17 Januari 2016];4(1):243-247. dari: http://jurnal.fk.unand.ac.id/index.php/jka/arti cle/view/229

[11] Taufiq I. Pengaruh latihan Range of Motion (ROM) ankle terhadap proses penyembuhan ulkus kaki diabetik di RSUD Dr.Hi.Abdul Moeloek dan RSUD Jendral A.Yani Propinsi Lampung. Tesis. Depok: Program Studi Pascasarjana IImu Keperawatan Universitas Indonesia;2011

[12] Griwijoyo, Dikdik. IImu faal olahraga fisiologi olahraga. Bandung: Remaja Rosda Karya; 2012.

[13] Ganong WF. Buku ajar fisiologi kedokteran. Edisi 22. Jakata: EGC; 2008.

[14] Sunaryo T, Sudiro. Pengaruh senam diabetik terhadap penurunan risiko ulkus kaki diabetik pada pasien DM tipe 2 di perkumpulan diabetik.Jurnal Terpadi IImu Kesehatan [Internet]. 2014 [diambil tanggal 16 Februari 2016];3(1):99-105 dari: http://www.poltekkessolo.ac.id/attachments/226 PENGARUH \%20SENAM \%20DIABETIK\%20

[15] Sukatemin. Kejadian ulkus kaki diabetik : kajian hubungan $\mathrm{HbA} 1 \mathrm{C}$, hiperglikemia, dislipidemia dan status vaskuler berdasarkan pemeriksan ankle brachial index/ABI. Tesis. Yogyakarta: Program Studi Magister Keperawatan Universitas Muhammadiyah Yogyakarta; 2013.

[16]Ahmad W, Khan Al, Ghaffar S, Al-Swailmi FA, Khan I. Risk factors for diabetic foot ulcer. J Ayub Med Coll Abbottabad [Internet]. 2013 [diambil tanggal 15 Mei 2016];25(1):8-16.dari:

http://www.ayubmed.edu.pk/JAMC/251/Wasim.pdf

[17] Suhartini P. Teori penuaan, perubahan pada sistem tubuh dan implikasinya pada manusia. Skripsi. Semarang: Program Studi IImu Keperawatan Universitas Diponegoro;2010.

[18] Khaier N. Faktor-faktor yang mempengaruhi kejadian ulkus diabetikum pada pasien diabetes melitus tipe 2. Jurnal IImu Keperawatan Indonesia[Internet] .2015 [diambil tanggal 15 Mei 2015];5(2):1-19. dari;

http://journal.stikim.ac.id/journal/pdf/JURNA L\%20KEPERAWATAN/JURNAL\%20PDF

[19] Sugiarto I. Faktor risiko yang berhubungan 
dengan terjadinya ulkus diabetik pada pasien diabetes melitus tipe 2 di Rsud. Dr. Margono Soekarjo Purwokerto.Skripsi. Purwokerto: Universitas Jendral Soedirman.

[20] Lestari D, Citrakesumasari, Alharini S. Upaya penanganan dan perilaku pasien penderita diabetes melitus tipe 2 di Puskesmas Maradekaya Kota Makassar. [Internet] 2013 [diambil tanggal $26 \mathrm{Mei}$ 2016] dari https://www.mysciencework.com/publication /show/dfeb14bf6546aba958df6c84be41748 2

[21] Price SA, Wilson LMC. Patofisiologi: konsep klinis proses-proses penyakit, edisi 6 , vol 2, Alih bahasa, Brahm U.Pendit. Jakarta: EGC;2006.

[22] Semendawai RK. Pengaruh latihan fisik senam kaki terhadap efektivitas fungsi sensori di daerah telapak kaki pada penderita diabetes melitus di Puskesmas Kedung Mundu Kota Semarang Jawa Tengah. Skripsi. Semarang: Fakultas IImu Keperawatan dan Kesehatan Universitas Muhammadiyah Semarang; 2013.

[23] Tandra $\mathrm{H}$. Segala sesuatu yang harus anda ketahui mengenai diabetes dengan cepat dan mudah. Jakarta: PT. Gramedia Pustaka Utama; 2007.

[24] Isral GN, Afriwardi, Sulastri D. Hubungan aktivitas fisik dengan kadar nitric oxide (NO) plasma pada masyarakat di Kota Padang. Jurnal Kesehatan Andalas[Internet]; 3(2):173-1772014[diambil tanggal 11 Juni 2016] dari: http://lib.ui.ac.id/file? file=digital $/ 20300843-T 30470 \% 20$ \%20Pengaruh\%20senam.pdf

[25] Jenkins L. Maximizing range of motion in older adults. The Journal on Active Aging[Internet] 2005 [diambil tanggal [10
Juni 2016] dari: http://www.humankinetics.com/acucustom/si tename/Documents/Documentltem/rangeof motion.pdf

[26] Fernando DJS, Masson EA, Veves A, Boulton AJM. Relationship of limited joint mobility to abnormal foot pressure and diabetic foot ulceration. Diabetes care[Internet]. 1991 [diambil tanggal 07 Juni 2016];14(1): 8-11.dari: http://care.diabetesjournals.org/content/diac are/14/1/8.full.pdf

[27] Andreassen CS, Jakobsen J, Andersen H. Muscel weakness : a progressive late complication in diabetic distal symmetric polyneuropathy. Diabetes[Internet] 2006 [diambil tanggal 13 Juni 2016];55(3):806812.

dari: http://www.ncbi.nlm.nih.gov/pubmed/165052 $\underline{47}$

[28] Widyawati IY. Pengaruh latihan rentang gerak sendi bawah secara aktif (Active Lower Range of Motion Exercise) terhadap tanda dan gejala neuropati diabetikum pada penderita DM Tipe II di Persedia Unit RSU Dr. Soetomo Surabaya. Tesis. Depok: Program Paska Sarjana Fakultas IImu Keperawatan Universitas Indonesia; 2010

[29] Sumpio. Foot ulcers.[Internet] New Haven; 2000 [diambil tanggal 07 Juni 2016]dari : http://www.nejm.org/doi/full/10.1056/NEJM2 00009143431107

[30] Misnadiarly. Diabetes mellitus : ulcer, gangren, infeksi [Intenet] Jakarta: Pustaka Populer Obor; 2006 [diambil tanggal 11 Juni 2016]

dari: https://books.google.co.id/books? id=UYMwK10k92kC\&printsec=frontcover\#v =onepage\&q\&f=true 